\title{
Mode of entry, loan portfolio structure, and returns of foreign-owned banks in Indonesia
}

\author{
Apriani D.R. Atahau \\ Universitas Kristen Satya Wacana, Salatiga-Indonesia \\ apriani@staff.uksw.edu \\ Tom Cronje \\ School of Economics, Finance and Property, Curtin University- \\ Australia, GPO Box U1987 Perth, Western Australia \\ Tom.Cronje@cbs.curtin.edu.au
}

\section{Shabri Abd. Majid*}

Universitas Syiah Kuala, Banda Aceh, Indonesia

mshabri@unsyiah.ac.id

${ }^{*}$ Corresponding author

Abstract. This study empirically examines whether the mode of entry into the Indonesian banking sector affects loan portfolio structures and loan interest rates of foreign-owned banks (FBs). It also attempts to explore whether the mode of entry affects loan portfolio returns of FBs in Indonesia. The data of all FBs were analyzed over the period from 2003 to 2011 using univariate statistics and pooled regression analyses. The study finds significant differences in the loan portfolio structures and loan interest rates of $\mathrm{FBs}$ based on different modes of entry into the Indonesian banking sector. In addition, FB mode of entry significantly affects loan portfolio returns. The findings show that the loan interest rates charged by $\mathrm{FBs}$ that acquired domestic banks are higher than the interest rates charged by greenfield FBs, although they have lower returns on assets and equity. The study also provides evidence that the loan portfolio structures of FBs that acquired domestic banks as a mode of entry, are more diversified than that of greenfield FBs. From an overall perspective, these findings imply that the loan portfolios of FBs that acquired domestic banks, are more diversified to different sectors of the economy, whilst the financial returns of greenfield FBs are more efficient.

Keywords: portfolio theory, acquired foreign banks, greenfield foreign banks, concentration.

JEL Classification: G21, G28, G34, L11 


\section{INTRODUCTION}

Foreign-owned banks (FBs) are generally established when they follow their home country's multinational customers and/or pursue opportunities in host countries (Cull \& Peria, 2010). Similarities in institutional, regulatory, economic, and cultural aspects between the parent bank country of origin and its subsidiary (or foreign branch) country serve as another consideration (Cull \& Peria, 2013). Vencappa and Thi (2007) refer to these motives as follow-the-client behaviour and profit-seeking behaviour based on traditional multinational banking theories. These theories indicate that multinational banks may prefer less intensive competitive markets with low entry barriers, but with large market sizes and high growth rates.

Based on the traditional multinational banking theories, Cerutti et al. (2007, p. 1670) document that FBs often expand their presence to non-local geographical areas by either acquiring "domestic institutions with extensive branch networks" or by establishing "isolated representative offices aimed at serving niche market segments". In Latin America and Eastern Europe, the bank branch establishment is the preferred method when host country taxes are high and foreign banks do not target retail segments (Dell'Ariccia and Marquez, 2010; Cerutti et al., 2007). In a host country in which there is a substantial possibility of expropriation, parent foreign banks prefer having branches rather than subsidiaries. In essence, the choice between branches and subsidiaries largely depends on the risks involved from a parent bank's desired market activity in a foreign country.

According to Brainard's (1993) trade-off theory, the selection between cross-border lending or financial foreign direct investment depends on the trade-off between fixed and variable costs (Vencappa and Thi, 2007). When fixed costs exceed variable costs, cross-border lending is the option and vice versa. In cases where direct foreign financial investment is considered, the mode of entry is also implicated by costs. In situations where domestic banks (DBs) in foreign countries are acquired as a mode of entry (hereinafter referred to as acquired FBs), the marginal costs may be higher than establishing new FB entities (greenfield FBs) since inferior facilities, operations and markets of the acquired banks may require large restructuring costs. However, greenfield FBs may face a soft information disadvantage, since they do not have prior lending relationships, which may result in higher marginal costs (Lehner, 2009). In their study of the Central and Eastern European countries over the period of 1995-2003, Havrylchyk and Jurzyk (2006) found that the mode of FB entry is one of the determinants of bank profitability. The greenfield FBs were more profitable than acquired FBs. Considering the impact of the FB mode of entry on information and bank lending rates, Claeys and Hainz (2006) found that greenfield FBs charged lower lending rates as they focus more on non-opaque borrowers (large enterprises with hard information available). A study by Lehner (2009) concluded that decisions about multinational bank modes of entry depend on the size of market entry costs, their relative disadvantage with regard to soft information access and their knowledge of the local market.

Advances in technology, the integration of financial systems, and increased liberalisation have enhanced foreign bank presence in countries (Claessens \& Horen, 2014). By relaxing the regulations regarding foreign bank entry and operation, many countries, including Indonesia have eased the establishment of foreign banks. As stated by Vencappa and Thi (2007), the expansion by banks in search of profits is improved by new "deregulation, transition, and crisis" opportunities. Since many Indonesian banks were not financially able to participate in the recapitalisation program after the 1997 financial crises (Montgomery, 2003), Indonesia had to raise the limit of foreign ownership in DBs from 51\% to 99\%, through the enactment of Government Regulation, Number 29/1999. Since then, the FBs could operate anywhere in Indonesia as a branch, a subsidiary (through direct investment or capital market investment) and a representative office. The majority of FBs chose to acquire shares in the existing domestic banks rather than establishing new branches (Goeltom, 2005). This situation provides evidence 
of the opportunities created by the financial crisis for FBs to enter host countries through acquisition (Hryckiewicz \& Kowalewski, 2010).

Over the last decade, the number of FBs in Indonesia decreased from 43 in 1999 to 34 in 2002 (Bank Indonesia Annual Report, 2003). From 2003 to 2011, the number of FBs increased from 27 to 37 due to the relaxation of regulations on foreign ownership in DBs, whereas the number of DBs declined. However, the number of government-owned banks (GBs) remained unchanged (30 banks) over the period.

Although the number of FBs increased over the 2003-2011 period, FBs experienced a decline in their market share as a percentage of total bank assets from $36 \%$ in 2003 to $25 \%$ in 2011 . The decline of their market share was more prevalent in the post-2008 global financial crises. It declined 15\% from 2008 to 2011 compared to the 11\% decline over the 2003-2007 period (Indonesian Banking Statistics, 2012). The market share reduction was caused by the transmission of crisis from their home countries (De Haas and Neeltje, 2011) and the reduction of lending to corporate borrowers (Cull \& Pería, 2013).

Many empirical studies documented that the presence of FBs in developing countries, including Indonesia have been increasing (Claessens et al., 2001; Claessens et al., 2010; Claessens et al., 2008; Clarke et al., 2001a; Clarke et al., 2001b; Clarke et al., 2002; De-Haas \& Van Lelyveld, 2006; De-Haas \& Naaborg, 2006; Montgomery, 2003; Unite \& Sullivan, 2003; Cull \& Peria, 2010; Chen \& Liao, 2011; and Giannetti \& Ongena, 2012). For example, Morutan and Badulescu (2016) investigated the FB mode of entry in emerging Central and Eastern European markets with a focus on the impact of it on their overall strategies before and after the financial crises.

The increased presence of FBs in the developing countries, especially Indonesia provides motivation for this study to further explore their entry motivation; their modes of entry; their relative performance compared to government and domestic-owned banks in the country; and their contribution to lending and financial sector development in host countries during both normal time periods as well as during economic crises time periods. Thus, a major novelty of this study is that its uses of unique data set of individual foreign-owned bank loan portfolios (based on the economic sector categories and the loan types) from the annual reports of banks and the Indonesian Banking Directory. In addition, this study captures the impact of foreign-owned presence in Indonesia on the FB loan portfolio returns by focusing on the different modes of the FB entry that have been ignored in previous studies. Thus, to the best of our knowledge, our study is the first attempt to explore empirically the impact of different modes of FB entry on loan portfolio compositions and returns of banks in the Indonesian banking industry.

The findings of the study are important, since according to Lehner (2009), the screening efficiency of banks, as the key determinant for the selection of the mode of entry would determine the quality of FB credit portfolios. Therefore, examining the relationship between foreign bank mode of entry and their loan portfolio structure and performance would fill the existing research gap and contribute to the enrichment of the existing literature in banking research from the perspective of Indonesia.

This study provides empirical evidence of the FB performance in the largest developing country in South East Asia. Indonesia is a country with the highest credit growth of all ASEAN countries, but ironically the amount of credit provided is still the lowest and Indonesian banks are still operating at higher net interest margins as compared to banks in the other ASEAN countries (Muljawan et al., 2014). These aspects single Indonesia out from other Asian countries. Thus, studying the presence of foreign banks in the distinctive nature of the banking industry in the largest emerging market of Indonesia would enrich the existing empirical literature on the existence of foreign banks in the host country.

The findings of this study confirmed the impact of FB mode of entry on their loan portfolio concentration, interest rates and returns to banking practitioners, investors, bank customers, and policymakers. The findings of this study show that the acquired FBs and the greenfield FBs differ with 
regard to loan portfolio concentration, interest rates, and returns. The loan portfolios of the greenfield FBs are more concentrated and focused on the manufacturing sector, whereas the acquired FBs have more diversified loan portfolios with more exposure to other sectors (primarily consumers) although a high level of concentration in the trade sector started in 2006.

Furthermore, differences in the loan portfolio composition and concentration between the greenfield FBs and the acquired FBs also reflect differences in loan repayment default risk. Their NonPerforming Loans (NPLs) differed the most from each other in 2003, but the difference becomes smaller from 2009 onwards. One major factor that contributed to the decrease in the NPL difference is the Central Bank Regulation (PBI 2/11/PBI/2000 jo PBI 15/2/PBI/2013) that implemented a $5 \%$ standard for the net NPL ratio of banks; prudential regulations (like productive asset quality, loan loss provision, and loan restructuring) enacted by the Central Bank since 2003 (Indonesian Banking Booklet, 2003 and 2011). Consequently, the interest rates of acquired FBs exceeded that of greenfield FBs, although the return on assets (ROA) and returns of equity (ROE) of greenfield FBs exceeded that of acquired FBs. These findings are aligned with the findings of Havrylchyk and Jurzyk (2006) for the case of the Central and Eastern European Countries where the greenfield FBs experienced higher returns than those of acquired FBs.

The rest of this study is structured as follows: the literature review is provided in Section 2. Section 3 discusses the research methodology applied in this study, followed by the findings and their discussion in Section 4. Finally, Section 5 concludes the study.

\section{LITERATURE REVIEW}

\subsection{Mode of entry and loan portfolio structure}

Previous studies on the presence of the FBs in host countries and their lending behaviour mainly consider information asymmetry, hierarchical structure distances between parent banks and subsidiaries/branches, and bilateral factors such as common language and legal frameworks (Cull and Peria, 2013, Feenstra et al., 2014). Information asymmetry refers to the lack of the material knowledge and understanding of FBs compared to existing domestic banks in host countries to which they expand their activities. Hierarchical distance exists because there are generally large numbers of organisational layers or hierarchies between home country chief executive officers (CEOs) and foreign loan officers (Mian, 2006). Foreign-owned banks with less hierarchical structures (less decision-making levels, cultural difference and less geographical distance between the parent bank and their overseas branches/subsidiaries) are more capable of dealing with "soft"-information borrowers. Common language and legal framework similarities between countries also enhance FB participation. The annual reports of entities published in the language of a specific country attract more investors from those countries (Grinblatt \& Keloharju, 2001).

Differences in the legal and regulatory frameworks between the home and host countries can affect the achievement of shareholder goals by requiring managers in the foreign country to comply with either fewer or additional regulations. Hierarchical structures, language differences, and legal frameworks are issues that are considered in previous research within the context of the comparison between FBs and DBs. Soft information represent the aspect that differentiates greenfield FBs and acquired FBs the most substantially from each other.

According to Degryse et al. (2009, 2012), the greenfield FBs have less access to loan information about domestic borrowers, which increase their information asymmetry with regard to these borrowers. Since the greenfield FBs have less information about domestic borrowers (incumbent firms), they focus more on the transparent-large borrowers in a more competitive market segment (Dell'Ariccia \& Marquez, 
2004). Degryse et al. $(2009,2012)$ argue that the greenfield FBs have an advantage in lending based on hard information, consisting of credit history and detailed financial statement information (Dell'Ariccia \& Marquez, 2004; and Detragiache et al., 2008). They are also in a better position to lend to multinational corporations headquartered in their home countries. Vencappa and Thi (2007) state that differences in the performance of acquired and greenfield FBs may also be explained by differences in the nature of their activities. Accordingly, the greenfield FBs focus on multinational clients and large local corporations that represent lower-risk customer categories and their loan portfolios are also more homogenous than that of acquired FBs. When banks enter host country markets in less developed countries by way of greenfield investments, they retain their international reputation which gives more security to depositors for banking with the reputable foreign bank. They may target specific market segments without commitments to prevailing loan portfolios that acquired FBs may have. Degryse et al. (2012) state that the portfolio concentration is stronger for greenfield FBs due to their larger information disadvantage compared to that of acquired FBs.

Loan portfolio concentration of greenfield FBs on transparent-large borrowers may entail lower risk exposure and lower interest income spreads based on the lower risk. Taking into consideration the extent of competition and interest rate returns of the FBs, Claeys and Hainz (2006) argue that the mode of entry affects the level of competition. The competition between all bank ownership types is stronger when the entry is predominantly in the form of greenfield investments since it represents an increase in the number of banks in the host country. This is supported by the study of (Martinez-Peria \& Mody, 2004) in Latin American countries. Their findings show an aggressive price setting by greenfield FBs to gain increased market share.

Based on the above discussion, the first two sub-hypotheses of the study are:

H1a: Loan portfolios of greenfield FBs are more concentrated than the loan portfolios of acquired FBs because they focus more on transparent large borrowers.

H1b: Loan portfolio interest rates of greenfield FBs are lower than the interest rates of acquired FBs because they focus more on lower risk transparent large borrowers.

\subsection{Performance of the foreign-owned banks}

According to Havrylchyk and Jurzyk (2006), the greenfield FBs were reluctant to engage in relationship lending because they were more independent with large deposit networks from their parent banks. This, in turn, affects the currency composition of their loan portfolios with more foreign currency loans available for their host country borrowers (Degryse et al., 2012). In contrast, the Domestic-owned banks (DBs) have the ability to gain knowledge from soft information provided by opaque firms that can produce less hard information. This is achieved by way of relationship lending (Berger \& Black, 2011). The FBs that take over the existing DBs may, therefore, experience a different situation since relationship lending may exist and continue after the acquirement. The exposure of acquired FBs to soft information borrowers creates loan quality uncertainty (Abarbanell \& Bonin, 1997). The acquired FBs may have incompatible market segments with their overall market positioning of the parent bank. The acquired FBs may need transitional time to improve their lending practices and improve the quality of their loan portfolios. Nevertheless, the acquired FBs have better access to local borrowers which enable them to target the retail segment and other local lending. This is advantageous for acquired FBs with little information about host countries (Lehner, 2009).

Vencappa and Thi (2007) state that greenfield FBs may perform better than acquired FBs when they focus on servicing multinational clients and big local corporations and provide trade services. They 
outperform acquired banks in terms of operating expenses, employment costs and profitability based on the findings of Majnoni et al. (2003) in Hungary who used accounting cost and profit measures of banks. Similar results were also found in the Polish banking industry in a study by Havrylchyk and Jurzyk (2006). Degryse et al. (2012) also state that the financial performance of greenfield FBs is better than that of acquired FBs due to their larger efficiency advantage.

Notwithstanding the empirical findings, Lehner (2009) states that greenfield FBs may have higher variable costs in terms of accessing soft information borrowers (Lehner, 2009). The difference in the performance of greenfield FBs and acquired FBs may be explained by the nature of the inherited problems faced by acquired FBs, the corporate governance structure adopted after the acquisition, the age effect, the structure of activities, and bank size (Vencappa \& Thi, 2007). Bank size may also serve as a differentiation factor since greenfield FBs are mostly smaller in size than acquired FBs which normally acquire large DBs (Havrylchyk \& Jurczyk, 2006). Foreign banks operating in different countries, irrespective of their own sizes as subsidiaries, possess diversification abilities based on the capital backing from their parent companies. This is based on the finding of Demsetz and Strahan (1997) that a positive relationship exists between the size of bank holding companies and the diversification applied by subsidiaries. However, the market focus of the holding companies may also serve as directives to the subsidiaries and not necessarily represent diversification in the countries where subsidiaries are located.

Thus, based on the above explanation, the study proposes the following hypothesis:

H2: The performance of greenfield FBs measured in terms of ROA and ROE exceed the performance of acquired FBs.

\subsection{Foreign bank entry into the Indonesian banking sector}

FBs have been expelled from the Indonesian market in the 1950s, but with the enactment of Banking Act No. 14/1967 (McLeod, 1996; and Montgomery (2003) they again gained access in the form of branches and representative offices. Ten FB branches were then established in the Indonesian capital city of Jakarta although their operations were restricted to non-deposittaking activities (McLeod, 1996). Their primary activity was to supplement the supply of capital to medium-size and large businesses (Suyatno, 1999). However, after two years, the government banned any further new FB entries (Montgomery, 2003). This banning remained valid until 1988 when numerous bank establishment regulations were relaxed to foster competition in the banking industry (Harun, 2008). Since then, foreigners and Indonesian citizens were allowed to establish joint-venture banks with permission to open sub-branches in seven major Indonesian cities, namely: Surabaya, Semarang, Bandung, Medan, Ujung Pandang, Denpasar, and Batam. However, the condition that applied was that at least $50 \%$ of the loan portfolios of the joint-venture banks had to support Indonesian export activities after one year of establishment. After the release of the central bank regulation regarding commercial banks (PBI 2/27/PBI/2000), this condition no longer exists since the regulation treats the joint venture and domestic banks equally.

As a result, the number of FBs increased from 11 in 1988 to 29 in 1991 (Pangestu, 2003). FB diversification to retail-banking also took place in addition to their focus on export support. The number of FBs also increased from 30 in 1992 to 44 in 1998, but due to the 1997 Asian financial crisis, their number decreased from 43 in 1999 to 34 in 2002 (Bank Indonesia Annual Report, 2003). However, since 2003, the Indonesian banking industry experienced new foreign investment with an increase in the number of FBs to 37 in 2011 and to 38 in 2016. 


\section{METHODOLOGY}

\subsection{Sample and data}

This study utilizes secondary data from the Indonesian Central Bank Library, Infobank magazine and the library of the Indonesian Banking Development Institute (LPPI). The central bank library provides individual bank ownership data and financial statements, whereas the Infobank magazine provides loan allocation data based on the loan types and economic sectors. Information from the Lembaga Pengembangan Perbankan Indonesia (LPPI) or Indonesian Banking Development Institute (IDBI) also supplements loan allocation data and loan interest income that are not available in the Infobank magazine. The data of all conventional FBs registered in Indonesia over the 2003-2011 study period are analysed in the study. Hence, saturation sampling or census is applied. It comprises the observation of 106 acquired FB years and 189 greenfield FB years. In total, these $295 \mathrm{FB}$ observation years constitute $30 \%$ of the 981 total commercial bank observation years in Indonesia over the study period 2003 to 2011. The criteria of Mian (2003) and Magalhaes et al. (2010) are applied to calculate the total ownership percentage of each bank. This research uses the 50\% direct ownership threshold, similar to the previous studies by Mian (2003), Barth et al. (2004), Micco et al. (2007), and Berger et al. (2010).

However, due to the enactment of the Indonesian government regulation No. 29 (1999), aimed at strengthening bank capital in the country after the 1997 Asian financial crisis, the focus of this paper is on the 9 years (2003-2011) after the 2000-2002 period of the Indonesian financial stabilization. The study period is relevant and sufficient to provide insightful empirical findings about foreign banks in Indonesia. Moreover, it includes the activities and performance of the FBs in Indonesia in the pre- and post-2008 global financial crisis time period. Finally, the requirement of the Indonesian central bank pertaining to the sectoral allocation of loans since 2012 has limited the study period since the loan classification that applied until 2011 cannot be integrated with the new loan classification introduced in 2012. We believe that the study pertaining to the 106 acquired FB observations and 189 greenfield FB observations over the 9-year period provides comprehensive analysis findings.

\subsection{Variables' definition and their measurements}

For Hypothesis 1a, the loan portfolio concentration is measured by the Hirschman Herfindahl Index (HHI), which has been widely used in previous studies about loan portfolio concentration (Winton, 1999; Acharya et al., 2006; and Hayden et al., 2007). This study focuses on the Economic Sector HHI (E-HHI) and the Loan Type HHI (T-HHI). Two primary independent variables are investigated in the study, namely the FB mode of entry and loan portfolio concentration. The FB ownership types consist of two groups, namely, acquired FBs and greenfield FBs. This classification is aligned with the classification applied by Degryse et al. (2012). The categories are differentiated by the dummy variables 1 for the acquired FBs and 0 otherwise to represent the two different modes of entry.

The study also incorporates controlled variables namely bank age, bank size, bank equity, bank liquidity, and loan repayment default risk (NPL) to represent bank-specific characteristics. These variables are used since they are considered as the determinants of bank performance (Pasiouras \& Kosmidou, 2007, Athanasoglou et al., 2008, Sufian, 2011). For bank size, the study uses the natural logarithm of total assets; bank equity is measured by the ratio of total equity to total assets; liquidity is measured by the ratio of total loans to total deposits; bank age is calculated based on the time difference between the year of establishment of the FB and the data year in the study period; and NPL to total loans is the proxy of loan repayment default risk. It differs from previous research 
by Athanasoglou et al. (2008), Sufian (2011), and Dietrich and Wanzenried (2011) where the ratio of loan loss provision to total loans was used as the measure of credit risk. Loan loss provision is subject to regulation and bank manager subjectivity. NPL gives a good proxy for the level of loan portfolio risk exposure as it serves as an actual measure of the total value of loans where losses may emanate due to non-compliance with repayment requirements. Within this context, it represents more overall non-adjusted credit risk data than the loan loss provision credit risk measure used in previous studies.

In Indonesia, there are 10 economic sectors to which banks can lend. Bank Indonesia, the Central Bank of Indonesia, classifies economic sectors into agriculture, hunting and agricultural facilities; mining; manufacturing; electricity gas and water; construction; trade, restaurants and hotels; transportation, warehousing, and communications; business services; social services; and others. Meanwhile, the loan types are categorized into three groups, namely: working capital, investment, and consumption.

Next, loan interest income (after loan repayment defaults) as a percentage of average total loans, shows whether overall loan pricing differences exist between acquired FBs and greenfield FBs). It is therefore applied as the dependent variable for Hypothesis 1b. The application of the loan interest income ratio is appropriate for Indonesia as an emerging market where lending remains the major activity of banks and interest income from loans contributes significantly to the overall bank income. This ratio reflects the quoted loan rates of banks for their loans. The ratio of total loans to total assets in Indonesia for the period 2005-2009 was 52\% on average, with loan income contributing 39\% of total bank income.

Loans account for approximately $65 \%$ of total bank assets based on data from Indonesian banking statistics for the year of 2016 whilst, on the other hand, the loan interest income represents an average of $52 \%$ of the total bank income during that period. The change in the average sizes of Indonesian bank loan portfolios as percentage of total assets and the increase in the average percentage of income from the loan portfolios show that the proportional increase in the interest income of banks $((0.52-0.39) / 0.39=33.233 \%)$ is higher than the increase in the average size of the loan portfolios $((0.65-0.52) / 0.52=25.00 \%)$.

Table 1

Variables Definition and Measurement

\begin{tabular}{|c|c|c|c|c|}
\hline No. & Variable & Definition & Measurement & Remarks \\
\hline 1. & $\begin{array}{l}\text { Loan Portfolio } \\
\text { Concentration (CONC) }\end{array}$ & $\begin{array}{l}\text { The risk arising from uneven distribution of } \\
\text { counterparties in the credit or any other business } \\
\text { relationships or from a concentration in business } \\
\text { sectors or geographical regions which is capable of } \\
\text { generating losses large enough to jeopardise an } \\
\text { institution's solvency (Deutsche Bundesbank, } \\
\text { 2006). }\end{array}$ & $H H I=\sum_{i=1}^{N}\left(\frac{p_{i}}{Q}\right)^{2}$ & $\begin{array}{l}\text { HHI }=\text { Hirschman } \\
\text { Herfindahl Index } Q= \\
\sum_{i=1}^{10} p_{i} \\
p i=\text { the percentage of } \\
\text { credit to each sector } \\
N=10 \text { for E-HHI } \\
\text { and } 3 \text { for THHI }\end{array}$ \\
\hline 2. & $\begin{array}{l}\text { Loan Portfolio Payment } \\
\text { Default Risk (RISK) }\end{array}$ & $\begin{array}{l}\text { A different risk inherent to each industry, region or } \\
\text { product of a bank (Cronje, 2013) }\end{array}$ & $\begin{array}{l}\text { (Substandard+Doubt- } \\
\text { ful+Loss)/Total Loans }\end{array}$ & \\
\hline 3. & $\begin{array}{l}\text { Loan Portfolio Return } \\
\text { (RETR) }\end{array}$ & The performance of loan portfolios & ROA and ROE & \\
\hline 4. & $\begin{array}{l}\text { Loan Interest Rates } \\
\text { (LITR) }\end{array}$ & $\begin{array}{l}\text { The income obtained from the bank's loan } \\
\text { portfolio }\end{array}$ & $\begin{array}{l}\text { Loan Interest Income/ } \\
\text { Total Loans }\end{array}$ & \\
\hline 5. & SIZE & $\begin{array}{l}\text { The accounting value of the bank total assets (in } \\
\text { the Indonesian Rupiah, IDR) }\end{array}$ & $\begin{array}{l}\text { Natural logarithm of } \\
\text { Total Assets }\end{array}$ & \\
\hline 6. & Equity (EQUITY) & $\begin{array}{l}\text { The book value of shareholder funds (Hogan et.al, } \\
\text { 2004) }\end{array}$ & $\begin{array}{l}\text { Total Equity/Total } \\
\text { Assets }\end{array}$ & \\
\hline 7. & Liquidity (LQDT) & $\begin{array}{l}\text { Ability to convert an asset into cash readily (Hogan } \\
\text { et.al, 2004) }\end{array}$ & $\begin{array}{l}\text { Total Loans/Total } \\
\text { Deposits }\end{array}$ & \\
\hline
\end{tabular}


Return on Assets (ROA) and Return on Equity (ROE) are applied as dependent variables. The calculation of ROA and ROE are based on the Indonesian Central Bank circular letter Number 3/30/DPNP (2001). ROA is measured by the ratio of income before tax to the average of total assets whereas ROE is measured by the ratio of income after tax to the average total equity. Table 1 provides the definitions of all variables and their measurements.

\subsection{Data analysis}

All variables in this study are quantitative in nature. To analyze the data, several steps are conducted. Firstly, the descriptive statistics analysis is performed to determine the tendency and deviation of data. Secondly, to test Hypothesis 1a the univariate statistics are, in the form of the test of means, used to scrutinise the differences in the loan portfolio concentration, risk, and interest rates of the acquired and greenfield FBs. The Mann-Whitney non-parametric test is the most suitable technique of analysis used for this purpose due to the non-normally data distribution.

Thirdly, the Breusch-Pagan Lagrangian multiplier test is applied in alignment with the methodology of Aivazian et al. (2005) to determine whether pooled regression or a fixed-effects model is most appropriate to test Hypotheses $1 \mathrm{~b}$ and 2 . The null hypothesis is that the individual effect $(\mu)$ is equal to zero. The test determines whether the estimated variance of the residuals from regression depends on the values of the independent variables. Since the test confirms that the variance of the residuals is independent of the values of independent variables, it confirms that pooled data regression should be applied. The fixed effects panel data regression does not allow the estimation of time-invariant coefficients (i.e., the effect of greenfield FB ownership on the loan portfolio returns); whereas the random effects panel data regression produces inconsistent parameter estimates. Finally, based on the Breusch-Pagan Lagrangian multiplier test results, pooled data regression equations are applied to test Hypotheses $1 \mathrm{~b}$ and 2. For Hypothesis $1 \mathrm{~b}$ the impact of the FB mode of entry, loan portfolio concentration and loan repayment default risk on the loan portfolio interest rates is estimated by:

$$
\text { Interest }_{i t}=\alpha_{i t}+\beta F_{B D m m y}+\lambda \mathrm{EHHI}_{\mathrm{it}}+\delta \mathrm{THHI}_{\mathrm{it}}+\gamma \text { Control }_{\mathrm{it}}+\varepsilon_{\mathrm{it}}
$$

The pooled data regression equation applied for Hypothesis 2 is the following:

$$
\text { Return }_{i t}=\alpha_{\text {it }}+\beta \text { FBDummy }_{i t}+\lambda \mathrm{EHHI}_{\mathrm{it}}+\delta \mathrm{THHI}_{\mathrm{it}}+\gamma \text { Control }_{\mathrm{it}}+\varepsilon_{\mathrm{it}} .
$$

Where Interest is the loan interest rates, Return is the loan portfolio returns (measured by ROA and ROE), FBDummy is the ownership dummy, EHHI is the economic sector loan portfolio concentration, THHI is the loan type portfolio concentration, Control is the vector of bank-specific controlled variables, $\alpha, \beta, \lambda, \delta$, and $\gamma$ are the estimated regression coefficients, it is the bank $i$ in year $t$, and $\varepsilon$ is the disturbance term.

\section{EMPIRICAL RESULTS AND DISCUSSION}

\subsection{Loan portfolio structure, interest, returns, and bank characteristics}

Table 2 provides the summary statistics of the loan portfolio compositions, the loan portfolio concentration structures, the returns and bank-specific characteristics of acquired FBs and greenfield FBs. 


\subsubsection{Loan portfolio Structure: acquired vs. greenfield FBs}

As reported in Table 2, the mean and standard deviation of the loan portfolio structures show that the loan portfolios of acquired FBs are more diversified than that of greenfield FBs for both economic sectors and loan types. The EHHI and THHI loan portfolio concentration of the acquired FBs and greenfield FBs over the study period (2003 to 2011) show that the concentration of the EHHI of the greenfield FBs is the highest during the entire study period, although their concentration decreased over the period 2005 to 2011. In contrast, the EHHI concentration levels of the acquired FBs tend to increase over the 2003 to 2009 period with a minor decrease from 2009 to 2011. Overall, the greenfield FBs show a diversification tendency over time. However, the level of diversification remain less than that of acquired FBs.

Moreover, the THHI levels of acquired FBs and greenfield FBs are very different over the period from 2003 to 2007, but the difference decreased from 2007 onwards since the acquired FBs tended to become more concentrated, while the loan portfolios of the greenfield FBs became slightly more diversified. However, its tendency is similar to that of the EHHI.

Table 2

Descriptive Statistics

\begin{tabular}{|c|c|c|c|c|}
\hline \multirow{2}{*}{ Variables } & \multicolumn{2}{|c|}{ Acquired FBs $(\mathrm{N}=106)$} & \multicolumn{2}{|c|}{ Greenfield FBs $(\mathrm{N}=189)$} \\
\hline & Mean & Std. Dev & Mean & Std. Dev \\
\hline \multicolumn{5}{|l|}{ 1. Loan Portfolio Structure: Concentration } \\
\hline By Economic Sector (EHHI) & 0.284 & 0.147 & 0.481 & 0.194 \\
\hline By Loan Types (THHI) & 0.560 & 0.187 & 0.714 & 0.202 \\
\hline \multicolumn{5}{|l|}{ 2. Loan Portfolio Structure: Composition } \\
\hline \multicolumn{5}{|l|}{ Based on Economic Sectors: } \\
\hline Agriculture & 0.025 & 0.029 & 0.033 & 0.087 \\
\hline Mining & 0.020 & 0.028 & 0.024 & 0.052 \\
\hline Manufacturing & 0.201 & 0.085 & 0.457 & 0.261 \\
\hline Electricity, Gas and Water & 0.003 & 0.001 & 0.008 & 0.055 \\
\hline Constructions & 0.044 & 0.061 & 0.017 & 0.036 \\
\hline Trade, hotel, and restaurants & 0.250 & 0.132 & 0.108 & 0.161 \\
\hline Transportation and Communication & 0.034 & 0.044 & 0.023 & 0.050 \\
\hline Business Services & 0.134 & 0.092 & 0.098 & 0.128 \\
\hline Social Services & 0.026 & 0.062 & 0.005 & 0.027 \\
\hline Others & 0.255 & 0.213 & 0.226 & 0.240 \\
\hline \multicolumn{5}{|l|}{ Based on Loan Types: } \\
\hline Working Capital & 0.605 & 0.231 & 0.716 & 0.259 \\
\hline Investment & 0.189 & 0.160 & 0.159 & 0.220 \\
\hline Consumption & 0.195 & 0.194 & 0.125 & 0.195 \\
\hline \multicolumn{5}{|l|}{ 3. Return (RETR) } \\
\hline Loan Interest Income Ratio & 0.155 & 0.220 & 0.082 & 0.045 \\
\hline ROA & 0.015 & 0.025 & 0.035 & 0.022 \\
\hline ROE & 0.112 & 0.112 & 0.147 & 0.127 \\
\hline \multicolumn{5}{|l|}{ 4. Bank Specific Characteristics } \\
\hline Payment Default Risk (RISK) & 0.035 & 0.044 & 0.042 & 0.053 \\
\hline Size & 15.736 & 2.792 & 15.751 & 1.236 \\
\hline Equity Ratio & 0.165 & 0.149 & 0.135 & 0.109 \\
\hline Liquidity Ratio & 0.808 & 0.366 & 0.987 & 0.585 \\
\hline Bank Age & 31.58 & 15.63 & 26.51 & 13.64 \\
\hline
\end{tabular}


Furthermore, as observed from Table 2, the loan portfolio composition for acquired FBs show that the others sector is their largest market followed by trade, and then manufacturing, whereas the greenfield FBs focus most on the manufacturing sector, followed by others, and then trade. The economic sector loan portfolio allocation of acquired FBs and greenfield FBs is depicted for each year of the study period (2003 to 2011). The acquired FBs focus primarily on four different economic sectors (trade, others, manufacturing and business services) with exposure ranging from $10 \%$ to $31 \%$ across the four sectors. The exposures to these sectors are volatile and changing significantly from year to year with an overall downturn in their loan exposure to the manufacturing sector. On the other hand, greenfield FBs focus primarily on the manufacturing sector with a decline in exposure from $57 \%$ in 2003 to $38 \%$ in 2011. Unspecified others is the second largest focus of the greenfield FBs with an increasing trend from $16 \%$ in 2003 to $21 \%$ in 2011 of exposure to this sector. Therefore, it is evident that the loan portfolio composition of the acquired and greenfield FBs differ, with the latter being more concentrated. These findings support the statement of Vencappa and Thi (2007) about the homogeneity of greenfield FB loan portfolios since they mainly focus on servicing multinational clients and the big local corporations.

Working capital loans represent the major loan type for both acquired and greenfield FBs, but the working capital loan concentration of greenfield FBs exceed that of acquired FBs (Table 2). Over the total study period, the working capital loans represent the vast majority of loans for both the acquired and greenfield FBs, although working capital loans of the acquired FBs increase from 47\% to 65\% from 2003 to 2011, whilst for greenfield FBs it decreases from $76 \%$ to $66 \%$ over the same period. In the case of the acquired FBs, their loan exposures to investment and consumer loans decline in totality from $52 \%$ to $35 \%$, while the loan exposures of the greenfield FBs increase from $24 \%$ to $34 \%$. It is evident that the THHI of the acquired FBs become more concentrated over time whilst the THHI of greenfield FBs become more diversified and that the loan type portfolio compositions of the two types of FBs are much more similar in 2011 than in 2003.

\subsubsection{Loan portfolio interest rates and returns: acquired vs. greenfield FBs}

The acquired FBs have higher loan interest rates than greenfield FBs (Table 2). Furthermore, the loan interest income ratios for the acquired and greenfield FBs show a small downward trend over the total 2003-2011 research period. This might relate to the changes in the central bank interest rate from $12.75 \%$ in 2005 to $6 \%$ in 2011 although banks apply different rates based, inter alia, on their specific market segments and the supply and demand for the loans that they provide. The acquired FBs show the highest loan interest income in all the years. Considering this situation, the acquired FBs, in general, apply higher interest rates than the greenfield FBs over the study period.

On the contrary, the ROA and ROE of greenfield FBs are higher than that of acquired FBs as shown in Table 2. It shows the efficiency of greenfield FBs as opposed to acquired FBs as stated by Lehner (2009) and Degryse et al. (2012).

\subsubsection{Bank-specific characteristics: acquired vs. greenfield FBs}

Furthermore, Table 2 shows the descriptive statistics of bank-specific characteristics of acquired and greenfield FBs. The average gross NPL of acquired FBs is lower (3.5\%) than the gross NPL of greenfield FBs (4.2\%). This serves as evidence that the risk exposure of the greenfield FBs is higher than that of the acquired FBs. The loan default risk for each year in the study period (2003 to 2011) illustrate the changes in the ratio of gross NPLs to total loans. The NPLs of the acquired FBs and greenfield FBs differ most from each other in 2003, but their differences decreased 
since 2009 (after the 2008 global financial crises). It also shows that the NPLs of the acquired FBs and greenfield FBs decreased from 2003 to 2011, which indicate a quality improvement in the portfolios of both acquired FBs and greenfield FBs.

The average sizes of both acquired FBs and greenfield FBs are very similar, but the sizes of acquired FBs differ more from each other than that of greenfield FBs. Considering the theory of parent bank backup for liquidity, the greenfield FB average liquidity level is higher than that of acquired FBs, although the differences in the liquidity levels of greenfield FBs are also higher. This indicates that, amidst the higher average liquidity level, there are also greenfield FBs with considerable high or even low liquidity levels. The average equity level of greenfield FBs is less than that of acquired FBs. Greenfield FBs also show more similarity in equity levels than acquired FBs. The average age of acquired FBs exceed that of greenfield FBs by approximately five years. It serves as an indication that the acquiring of domestic banks, may initially have dominated the FB mode of entry.

\subsection{The concentration of loan portfolios: acquired vs. greenfield FBs}

The result of the Mann-Whitney test to assess the differences in loan portfolio structure and performance between the acquired and greenfield FBs is displayed in Table 3. As observed in Table 3, there is a statistically significant difference in the loan portfolio concentration and interest rate income levels of the acquired and the greenfield FBs. The table shows that greenfield FB loan portfolios are more concentrated than that of acquired FBs. This is also supported by Table 4 (correlation coefficients) that shows a statistically significant negative correlation of the FB mode of entry with measures of concentration (EHHI and THHI).

Furthermore, relating these findings to the transparency of borrowers, the manufacturing sector is the largest market of greenfield FBs. This can be associated with "hard"-information customers, whilst the major market of acquired FBs is the others sector. This sector can be associated with "soft"-information customers that may include consumers and small informal enterprises (Table 2). Overall, these findings confirm that loan portfolios of greenfield FBs are more concentrated than the loan portfolios of acquired FBs. Thus, it supports Hypothesis 1a.

Table 3

Univariate Statistics of the Loan Portfolio Structure and Performance

\begin{tabular}{|c|c|c|c|c|c|}
\hline \multirow{2}{*}{ Variable } & \multirow{2}{*}{$\begin{array}{l}\text { Acquired FBs } \\
\quad(n=106)\end{array}$} & \multirow{2}{*}{$\begin{array}{c}\text { Greenfield FBs } \\
\quad(n=189)\end{array}$} & \multirow{2}{*}{ Difference } & \multicolumn{2}{|c|}{ Mann-Whitney Test } \\
\hline & & & & $\mathrm{Z}$ & Prob. \\
\hline EHHI & 0.284 & 0.481 & -0.197 & 10.702 & $0.000^{* * *}$ \\
\hline THHI & 0.560 & 0.714 & -0.154 & 6.134 & $0.000^{* * *}$ \\
\hline Risk & 0.034 & 0.042 & -0.008 & 0.113 & 0.910 \\
\hline Interest Rate & 0.155 & 0.082 & 0.073 & -8.195 & $0.000^{* * *}$ \\
\hline ROA & 0.015 & 0.035 & -0.02 & 6.835 & $0.000^{* * *}$ \\
\hline ROE & 0.112 & 0.147 & -0.05 & 1.958 & $0.050^{* *}$ \\
\hline
\end{tabular}

Note: The Mann-Whitney tests are conducted for testing the loan portfolio structure and performance median differences between the acquired and Greenfield FBs over the nine-year study period. *** indicates $1 \%$ level of statistical significance.

In addition to the support for Hypothesis $1 \mathrm{a}$, the negative correlation between size and loan portfolio concentration $(-0.390$ to -0.389$)$ in Table 4 shows that small FBs tend to have more concentrated loan portfolios. There are also statistically negative correlations between 
bank age and measures of loan portfolio concentration (-0.298 to -0.273$)$, implying that older FBs tend to have more diversified loan portfolios. However, a positive significant correlation exists between FB and loan portfolio returns (0.249).

Table 4

Coefficients of Correlation

\begin{tabular}{|l|c|l|l|l|l|l|l|l|l|l|l|}
\hline Variable & LITR & FB Dummy & EHHI & THHI & NPL & Size & LDR & Equity & Age & ROA & ROE \\
\hline LITR & 1.000 & & & & & & & & & & \\
\hline FB Dummy & $0.249^{* * *}$ & 1,000 & & & & & & & & & \\
\hline EHHI & $-0.148^{* *}$ & $-0.471^{* * *}$ & 1,000 & & & & & & & & \\
\hline THHI & $-0.123^{* *}$ & $-0.353^{* * *}$ & $0.520^{* * *}$ & 1.000 & & & & & & & \\
\hline NPL & 0.051 & 0.149 & -0.181 & $-0.224^{* * *}$ & 1.000 & & & & & & \\
\hline Size & 0.095 & -0.006 & $-0.390^{* * *}$ & $-0.389^{* * *}$ & -0.032 & 1.000 & & & & & \\
\hline LDR & -0.077 & -0.164 & 0.017 & 0.046 & 0.161 & -0.142 & 1.000 & & & & \\
\hline Equity & -0.049 & 0.114 & 0.026 & 0.092 & 0.091 & $-0.489^{* * *}$ & 0.276 & 1.000 & & & \\
\hline Age & 0.092 & $0.167^{* * *}$ & $-0.273^{* * *}$ & $-0.298^{* * *}$ & -0.043 & $0.516^{* * *}$ & -0.010 & $-0.290^{* * *}$ & 1.000 & & \\
\hline ROA & -0.054 & $-0.374^{* * *}$ & $0.134^{* *}$ & $0.188^{* *}$ & -0.033 & $0.104^{*}$ & $-0.225^{* * *}$ & -0.026 & $0.097^{*}$ & 1.000 & \\
\hline ROE & 0.079 & $-0.139^{* *}$ & -0.041 & -0.025 & -0.033 & $0.336^{* * *}$ & $-0.105^{*}$ & $-0.253^{* * *}$ & $0.308^{* * *}$ & $0.648^{* * *}$ & 1.000 \\
\hline
\end{tabular}

Note: ${ }^{* *}$ and $* *$ indicate $1 \%$ and $5 \%$ levels of statistical significance.

Furthermore, the average age of acquired FBs exceed that of greenfield banks by approximately 5 years (Table 2), indicating the tendency of acquired FBs to be more diversified than that of greenfield FBs. Thus, these significant relationships with the concentration of FBs show that in addition to the mode of entry, the size and age of FBs have a definite effect on their levels of concentration.

\subsection{Loan portfolio interest rates: acquired vs. greenfield FBs}

The Relationship between Loan Portfolio Returns and their Determinants ( $\mathrm{n}=295)$

\begin{tabular}{|l|c|c|c|}
\hline \multicolumn{1}{|c|}{ Variables } & Loan Interest Rate & ROA & ROE \\
\hline \multirow{2}{*}{ FB Dummy } & $0.073^{* * *}$ & $-0.017^{* * *}$ & $-0.043^{* * *}$ \\
\cline { 2 - 4 } & $(3.51)$ & $(-4.97)$ & $-2.52)$ \\
\hline \multirow{2}{*}{ EHHI } & 0.004 & -0.002 & $(-0.16)$ \\
\hline \multirow{2}{*}{ THHI } & $(0.08)$ & $(-0.18)$ & 0.055 \\
\cline { 2 - 4 } & 0.002 & $0.021^{* * *}$ & $(1.39)$ \\
\hline \multirow{2}{*}{ NPL } & $(0.05)$ & $(2.62)$ & 0.004 \\
\hline \multirow{2}{*}{ Size } & 0.003 & 0.001 & $(0.85)$ \\
\cline { 2 - 4 } & $(0.41)$ & $(0.56)$ & $(2.63)$ \\
\cline { 2 - 4 } Equity & 0.006 & $0.002^{*}$ & -0.047 \\
\hline \multirow{2}{*}{ Liquidity } & $(0.95)$ & $(1.89)$ & $(-0.74)$ \\
\hline \multirow{2}{*}{ Bank Age } & -0.04 & 0.012 & $-0.000^{*}$ \\
\hline \multirow{2}{*}{ Constant } & $(-0.51)$ & $(0.95)$ & $(-1.69)$ \\
\cline { 2 - 4 } & -0.00 & $-0.000^{* * *}$ & $0.002^{* * *}$ \\
\cline { 2 - 4 } & $(-0.30)$ & $(2.84)$ & $(3.74)$ \\
\hline
\end{tabular}

Note: These findings were estimated using the pooled regression of Equation 3.1. ${ }^{* * *}$, ${ }^{* *}$, and ${ }^{*}$ respectively correspond to $1 \%, 5 \%$, and $10 \%$ significance levels. The figures in brackets (.) show the t-statistics. 
Table 5 presents the findings from the pooled regression analysis, showing the relationship between the FB mode of entry, loan portfolio concentration, control variables, and the loan portfolio returns.

As reported in Table 5, the FB mode of entry significantly affects the loan interest rates. The positive coefficient of loan interest rates is more for the FB entry dummy regressor of acquired FBs compared to that of the greenfield FBs. The estimated relationship is statistically significant and supports previous empirical studies (Martines-Peria \& Mody, 2004, Claeys \& Hainz, 2006). Table 4 correlation matrix also shows a statistically significant positive correlation of $24.95 \%$ between the mode of entry and loan interest rate income. In addition, Table 2 shows the major market segment of acquired banks is the others sector. This sector can be associated with "soft"-information customers that may include consumers and small informal enterprise activities, whilst the major market sector for greenfield FBs is the manufacturing ("hard"-information) sector. It is therefore evident that the acquired FBs serve a higher-margin market segment than the greenfield FBs. Thus, this evidence supports Hypothesis 1b. In addition, the evidence for the hypothesis is aligned with the statements of Claeys and Hainz (2006) that competition between all bank ownership types is stronger when the entry is predominantly in the form of greenfield Investment. Martinez-Peria and Mody (2004) in their study on the Latin American countries found that greenfield FBs apply an aggressive price setting to gain increased market share.

\subsection{Performance of acquired vs. greenfield FBs}

As observed from Table 5, the study shows a statistically negative coefficient of the FB mode of entry with ROA and ROE, indicating that the performance of the greenfield FBs exceed that of acquired banks. This finding is supported by Table 2 and 4 that show the average ROA and ROE levels of greenfield FBs are higher than that of acquired FBs and that the differences are significant. It provides supporting evidence for Hypothesis 2. The finding is aligned with the finding of Havrylcyck and Jurzyk (2006) in the Central and Eastern European Countries, which indicates that greenfield FBs experience higher returns than acquired FBs since acquired FBs take over less profitable DBs. Our finding also support the findings of Martinez-Peria and Mody (2004) and Majnoni et al. (2003) that greenfield FBs experience higher profits than acquired FBs (Claeys \& Hainz, 2006). Furthermore, the finding of this study also support Degryse et al. (2012) that both the performance and portfolio composition are stronger for greenfield $\mathrm{FBs}$ due to their larger efficiency advantage and larger information disadvantage compared to that of acquired $\mathrm{FBs}$ and $\mathrm{DBs}$.

When considering the different FB bank characteristics that were applied as control variables in the test of the hypothesis, loan portfolio risk (NPL) show a significant negative relationship with the loan type concentration. The relationship between NPL and interest rates charged by FBs show that a minor positive relationship also exists between interest rates of banks and NPL levels, whilst NPL levels have similar minor negative effects on ROA and ROE.

Additionally, this study provides evidence that a significant negative relationship exists between bank size and both the economic sector concentration and loan type concentration levels of FBs. The larger the banks, the lower the concentration of their loan portfolios. The findings also show a significant positive relationship between bank size and loan portfolio returns (ROA and ROE) of FBs, implying that larger banks perform better due to definite advantageous differences in economics of scale.

Furthermore, the study finds no significant relationship between equity levels, the concentration levels, interest rates, ROA and ROE of FBs, but bank liquidity shows significant negative relationships with loan portfolio returns. It indicates that when banks apply higher precaution (higher liquidity 
holdings) they have lower interest rate returns on their loan portfolios and lower levels of ROA and ROE. However, the liquidity coefficient is small, showing that although the difference exists, it is minor.

The age of banks shows significant negative relationships with economic sector and loan type concentration levels. This imply that the longer FBs exist, the more diversified they become in terms of economic sectors and loan types. Significant positive relationships exist between bank age and loan portfolio returns (ROA and ROE), meaning that the longer banks exist the higher their returns are. Notwithstanding the significant relationships of age with ROA and ROE, the relationship with the interest rates of banks is insignificant. These findings support the findings by Vencappa and Thi (2007) that the older banks are more efficient than younger banks, thus experiencing higher returns.

Finally, the study found a $1 \%$ statistical significant relationship between the FB mode of entry and the loan interest rates, ROA, and ROE. This finding provides strong evidence that the acquisition of domestic-banks is the most preferred method for attaining higher interest rate income, but higher returns in terms of ROA and ROE is better achieved by way of Greenfield entry.

\section{CONCLUSION}

This study empirically explore whether loan portfolio structures, interest rates, and returns of acquired FBs and greenfield FBs in Indonesia differ over the period 2003-2011. The findings of this study support the hypothesis that the acquired and the greenfield FBs differ from each other with regard to loan portfolio concentration. The loan portfolios of the greenfield FBs are more concentrated and focus on the manufacturing sector, whereas the acquired FBs have more diversified loan portfolios with more exposure to the others (primarily consumers and small informal enterprises) sector followed by exposure to the trade sector. These findings support the statement of Vencappa and Thi (2007) about the homogeneity of greenfield FB loan portfolios that mainly focus on multinational clients and the large local corporations. The findings of the study also show that, in addition to the mode of entry, the size and age of FBs have a definite effect on their levels of concentration.

The finding that the loan portfolio interest rates of greenfield FBs are lower than that of acquired FBs is simply due to the focus of greenfield FBs on transparent large borrowers. This finding is in harmony with the study by Claeys and Hainz (2006) who documented that the competition between all bank ownership types is stronger when the entry is predominantly in the form of greenfield investment. In their study of the Latin American countries, Martinez-Peria and Mody (2004) documented that greenfield FBs apply aggressive price settings to gain increased market share.

Finally, the differences in the loan portfolio composition and concentration of the different FBs cause differences in the loan portfolio returns. The greenfield FBs record higher returns (ROA and ROE) than acquired FBs. These findings support the earlier study by Havrylchyk and Jurzyk (2006) that greenfield FBs experience higher returns than acquired FBs in the Central and Eastern European countries due to their acquisition of the less profitable domestic-banks. The studies of Martinez, Peria and Mody (2004), Majnoni et al. (2003), and Claeys \& Hainz, (2006) also support our findings that greenfield FBs experience higher profits than acquired FBs. Finally, our findings are also in harmony with the previous study by Degryse et al. (2012) who documented that both the performance and portfolio composition hypotheses are stronger for greenfield FBs due to their higher efficiency advantage and larger information disadvantage compared to those of acquired FBs and DBs.

The findings of this study could be used as important reference by the managers of parent foreign banks to formulate optimal entry strategies into host countries. Policymakers could also benefit from these findings in terms of regulations pertaining to the entry and presence of foreign banks in terms of the enhancement of the financial stability and economic development of host countries. This study adds to 
the existing literature about foreign-owned banks, but it does not address FB heterogeneity (such as $\square$ the type of acquired DBs, the FB country of origin, as well as culture, language and legal environment differences). Future research addressing the FB heterogeneity may provide more comprehensive answers to activity and performance differences between FBs. Although the period of study encompasses the global financial crises, a detailed analysis considering the impact of it with regard to pre- and the post-financial crises comparisons have not been addressed. Hence, future research might $\square$ study the effect of the economic crisis on the activities and performance of FBs with consideration of the effect of external impacts on parent banks and the transmission of such impact to subsidiaries in host countries.

\section{ACKNOWLEDGEMENT}

This paper has been thoroughly enhanced and improved during the mentoring program sponsored[ by the Alumni Professional Development Program (APDP) in 2017. The APDP has initiated the mentoring program to build research capability of Australian Alumni, led by Griffith University within a consortium and in partnership with Indonesian universities: Universitas Indonesia, Universitas Negeri Jakarta, and Universitas Hasanuddin.

\section{REFERENCES}

Abarbanell, J. S., \& Bonin, J.P. (1997). Bank privatization in Poland: The case of Bank Slaski, Journal of Comparative Economics, 25(1), 31-61. doi: https://doi.org/10.1006/jcec.1997.1447.

Acharya, V.V., Hasan, I., \& Saunders, A. (2006). Should banks be diversified? Evidence from individual bank loan portfolios. The Journal of Business, 79(3), 1355-1412. doi: 10.1086/500679.

Athanasoglou, P. P., Brissimis, S. N., \& Delis, M. D. (2008). Bank-specific, industry-specific and macroeconomic determinants of bank profitability. International Financial Markets, Institution and Money, 18(2), 121-136. doi: https://doi.org/10.1016/j.intfin.2006.07.001

Barth, J. R., Caprio, G. G., \& Levine, R. (2004). Bank regulation and supervision: What works best? Journal of Financial Intermediation, 13, 205-248. doi:10.1016/j.jfi.2003.06.002.

Berger, A. N., Hasan, I., \& Zhou, M. (2010). The effects of focus versus diversification on bank performance: Evidence from Chinese banks. Journal of Banking \& Finance, 34(7), 1417-1435. doi: https:// doi.org/10.1016/j.jbankfin.2010.01.010.

Berger, A.N., \& Black, L.K. (2011). Bank size, lending technologies, and small business Finance, Journal of Banking \& Finance, 35(3), 724-735. doi: https://doi.org/10.1016/j.jbankfin.2010.09.004.

Cerutti, E., Dell'Ariccia, G., \& Peria, M. S. M. (2007). How banks go abroad: Branches or subsidiaries? Journal of Banking \& Finance, 31(6), 1669-1692. doi: https://doi.org/10.1016/j.jbankfin.2006.11.005.

Chen, S.H., \& Liao, C.C. (2011). Are foreign banks more profitable than domestic banks? Home-and hostcountry effects of banking market structure, governance, and Supervision. Journal of Banking \& Finance, 35(4), 819-839. doi: https://doi.org/10.1016/j.jbankfin.2010.11.006.

Claessens, S., \& Horen, N. (2014). Foreign banks: Trends and impact. Journal of Money, Credit and Banking, 46(1), 295326. doi: https://doi.org/10.1111/jmcb.12092.

Claessens, S., Dell'Ariccia, G., Igan, D., \& Laeven, L. (2010). Cross-country experiences and policy implications from the global financial crisis. Economic Policy, 25(62), 267-293. doi: https://doi.org/10.1111/j.1 468-0327. 201 0.00244.x.

Claessens, S., Demirgüç-Kunt, A., \& Huizinga, H. (2001). How does foreign entry affect domestic banking markets? Journal of Banking \& Finance, 25(5), 891-911. doi: https:/ / doi.org/ 10.1016/ S0378-4266(00)00102-3.

Claessens, S., Van Horen, N., Gurcanlar, T., \& Mercado Sapiain, J. (2008). Foreign Bank Presence in Developing Countries 1995-2006: Data and Trends. Washington: The World Bank. doi: http:/ / dx.doi.org/10.2139/ssm. 1107295. 
Claeys, S., \& Hainz, C. (2006). Acquisition versus Greenfield: the impact of the mode of foreign bank entry on information and bank lending rates. ECB Working Paper No. 653. Available at SSRN: https://ssrn.com/abstract $=913324$

Clarke, G.R.G., Cull, R., \& Martinez-Peria, M.S. (2001a). Does foreign bank penetration reduce access to credit in developing countries?: Evidence from asking borrowers. World Bank Policy Research Paper. doi: https://doi.org/10.1596/1813-9450-2716.

Clarke, G.R.G., Cull, R., Martinez-Peria, M.S., \& Sanchez, S.M. (2001b). Foreign bank entry: experience, implications for developing countries and agenda for future Research. World Bank Policy Research Paper, 18, 25-29. doi: https://doi.org/10.1093/wbro/lkg002.

Clarke, G.R.G., Cull, R., \&Peria, M. S. M. (2002). Does Foreign Bank Penetration Reduce Access to Credit in Developing Countries? Evidence from Asking Borrowers. Development Research Group. Washington: The World Bank. https://doi.org/10.1596/1813-9450-2716.

Cronje, T. (2013). 11040, 10954 \& Bank 22 Bank Lending for Curtin University and Open Universities. Australia: McGrawHill.

Cull, R., \& Peria, M.S.M. (2010). Foreign Bank Participation in Developing Countries: What Do We Know about the Drivers and Consequences of this Phenomenon?. Washington: The World Bank. doi: https://doi.org/10.1596/1813-9450-5398.

Cull, R., \& Peria, M. S. M. (2013). Bank ownership and lending patterns during the 2008-2009 financial crisis: evidence from Latin America and Eastern Europe. Journal of Banking \& Finance, 37(12), 4861-4878. doi: https://doi.org/10.1016/j.jbankfin.2013.08.017.

De Haas, R., \& Naaborg, I. (2006). Foreign banks in transition countries: to whom do they lend and how are they financed?. Financial Markets, Institutions \&Instruments, 15(4), 159-199. doi: https://doi.org/10.1111/j.14680416.2006.00116.x.

De Haas, R., \& Van Horen, N. (2012). Running for the exit? International bank lending during a financial crisis. The Review of Financial Studies, 26(1), 244-285. doi: https://doi.org/10.1093/rfs/hhs113.

De Haas, R., Ferreira, D., \& Taci, A. (2010). What determines the composition of banks' loan portfolios? Evidence from Transition Countries. Journal of Banking Finance, 34(2), 388-398. doi: https://doi.org/10.1016/j.jbankfin.2009.08.005.

De Haas, R., \& Van Lelyveld, I. (2006). Foreign banks and credit stability in Central and Eastern Europe. A panel data analysis. Journal of Banking \& Finance, 30(7), 1927-1952. doi: https://doi.org/10.1016/j.jbankfin.2005.07.007.

Degryse, H., Havrylchyk, O., Jurzyk, E., \& Kozak, S. (2012). Foreign bank entry, credit allocation and lending rates in emerging markets: Empirical evidence from Poland. Journal of Banking \& Finance, 36(11), 2949-2959. doi: https://doi.org/10.1016/j.jbankfin.2011.12.006.

Dell'Ariccia, G., \& Marquez, R. (2004). Information and bank credit allocation. Journal of Financial Economics, 72(1), 185-214. doi: https://doi.org/10.1016/S0304-405X(03)00210-1.

Demsetz, R.S., \& Strahan, P.E. (1997). Diversification, size, and risk at bank holding companies. Journal of Money, Credit \& Banking, 29(3), 300-314. doi: 10.2307/2953695.

Detragiache, E., Tressel, T., \& Gupta, P. (2008). Foreign banks in poor countries: Theory and evidence. The Journal of Finance, 63(5), 2123-2160. doi: https://doi.org/10.1111/j.1540-6261.2008.01392.x.

Dietrich, A., \& Wanzenried, G. (2011). Determinants of bank profitability before and during the crisis: Evidence from Switzerland. Journal of International Financial Markets, Institutions and Money, 21(3), 307-327. doi: https://doi.org/10.1016/j.intfin.2010.11.002.

Feenstra, R. C., Li, Z., \& Yu, M. (2014). Exports and credit constraints under incomplete information: Theory and evidence from China. Review of Economics and Statistics, 96(4), 729-744. doi: https://doi.org/10.1162/REST_a_00405.

Giannetti, M., \& Ongena, S. (2012). Lending by example: Direct and indirect effects of foreign banks in emerging market. Journal of International Economics, 86(1), 167-180. doi: https://doi.org/10.1016/j.jinteco.2011.08.005.

Goeltom, M. S. (2005). Indonesia's Banking Industry: Progress to Date, Country Paper for BIS Deputy Governor Meeting, Bank for International Settlement. doi: http://dx.doi.org/10.2139/ssrn.1188516.

Grinblatt, M., \& Keloharju, M. (2001). How distance, language, and culture influence stockholdings and Trade. The Journal of Finance, 56(3), 1053-1073. doi: https://doi.org/10.1111/0022-1082.00355.

Harun, C. A. (2008). Essay on the Indonesian Banking Crisis and Restructuring, Ph.D. Thesis, Boston University. 
Havrylchyk, O., \& Jurzyk, E. (2006). Profitability of Foreign and Domestic Banks in Central and Eastern Europe: Does the Mode of Entry Matter? In: Economics, L. C.F.T. (ed.) LICOS Discussion Paper. Belgium: Katholieke Universiteit Leuven.

Hayden, E., Porath, D., \& Westernhagen, N. V. (2007). Does diversification improve the performance of German banks? Evidence from individual bank loan portfolios. Journal of Financial Services Research, 32(3), 123-140. doi: 10.1007/s10693-007-0017-0.

Hryckiewicz, A., \& Kowalewski, O. (2010). Economic determinates, financial crisis and entry modes of foreign banks into emerging Market. Emerging Markets Review, 11(3), 205-228. doi: https://doi.org/10.1016/j.ememar.2010.05.003.

Indonesian Banking Statistics. (2012). Indonesian Banking Statistics, Central Bank of Indonesia. BI: Jakarta.

Lehner, M. (2009). Entry mode choice of multinational banks. Journal of Banking \&Finance, 33(10), 1781-1792. doi: https://doi.org/10.1016/j.jbankfin.2009.03.009.

Magalhaes, R., Urtiaga, M. G., \& Tribo, J. A. (2010). Banks' ownership structure, risk and performance. doi: http://dx.doi.org/10.2139/ssrn.1102390.

Majnoni, G., Shankar, R., \& Varhegyi, E. (2003). The dynamics of foreign bank ownership- evidence from Hungary. World Bank Policy Research. Washington: World Bank. doi: https://doi.org/10.1596/1813-9450-3114.Martinez Peria, M. S., \& Mody, A. (2004). How foreign participation and market concentration impact bank spreads: Evidence from Latin America. Journal of Money, Credit, and Banking, 36(3), 511-537. doi: $10.1353 / \mathrm{mcb} .2004 .0048$.

Mian, A. (2003). Foreign, private domestic, and government banks: New evidence from emerging market. Journal of Banking \& Finance, 27(7), 1219-1410. doi: 10.1111/j.1540-6261.2006.00878.x

Mian, A. (2006). Distance constraints: The limits of foreign lending in poor economies. The Journal of Finance, 61(3): 1465-1505. doi: https://doi.org/10.1111/j.1540-6261.2006.00878.x.

Micco, A., Panizza, U., \& Yanez, M. (2007). Bank ownership and performance: Does politics matter?. Journal of Banking \& Finance, 31(1), 219-241. doi: https://doi.org/10.1016/j.jbankfin.2006.02.007.

Montgomery, H. (2003). The Role of foreign banking in post-crisis Asia: The importance of method of entry. $A D B$ Institute Research Paper. doi: http://dx.doi.org/10.2139/ssrn.1396106.

Moruțan, R.A., \& Bădulescu, D. (2016). State-owned, acquisition or greenfield banks in the new EU member states. A post-crisis analysis. Oradea Journal of Business and Economics, 1(2), 62-71.

Muljawan, D., Hafidz, J., Astuti, R.I., \& Oktapiani, R. (2014). Faktor-Faktor Penentu Efisiensi Perbankan Indonesia serta Dampaknya terhadap Perbitungan Suku Bunga Kredit. Jakarta: Bank Indonesia.

Pangestu, M. (2003). The Indonesian bank crisis and restructuring: lessons and implications for other developing countries. G-24 Discussion Paper Series. New York and Geneva: United Nations.

Pasiouras, F., \& Kosmidou, K. (2007). Factors influencing the profitability of domestic and foreign commercial banks in the European Union. Research in International Business and Finance, 21, 222-237. doi: https://doi.org/10.1016/j.ribaf.2006.03.007.

Sufian, F. (2011). Profitability of the Korean banking sector: Panel evidence of bank-specific and macroeconomic determinants. Journal of Economics and Management, 7, 43-72.

Unite, A. A., \& Sullivan, M. J. (2003). The effect of foreign entry and ownership structure on the Philippine domestic banking market. Journal of Banking \&Finance,27(12), 2323-2345. doi: https://doi.org/10.1016/S03784266(02)00330-8.

Vencappa, D., \& Thi, N.A.V. (2007). Decomposing the productivity growth of foreign banks in the Czech Republic, Hungary and Poland; Greenfield investment versus mergers and acquisitions. The ICFAI Journal of Mergers and Acquisitions, 4(4), 27-38.

Winton, A., Kocherlakota, N., Levine, R., \& Mitusch, K. (1999). Don't Put All Your Eggs in One Basket? Diversification and Specialization, Working Paper. University of Minnesota. doi: http://dx.doi.org/10.2139/ssrn.173615. 